\title{
Review
}

\section{Ethics and politics after post-structuralism: Levinas, Derrida, Nancy}

\author{
Madeleine Fagan, \\ Edinburgh University Press, Edinburgh, 2013, viii+208pp., £70.00, \\ ISBN: 978-0748685134 \\ Contemporary Political Theory (2015) 14, e216-e219. doi:10.1057/cpt.2014.26; \\ published online 28 October 2014
}

It has become almost a commonplace in the critique of post-structuralist ethics to attack their adherents for failing either to live up to the terms of their radical critique of traditional ethics and politics or to offer reliable criteria of judgement for evaluating between different ethical claims in politics. The common denominator behind these accusations is a reliance on foundationalist thinking in either assessing post-structuralist claims or critiquing foundationalism's strange and paradoxical reemergence in radical discourses that claim to have escaped it. Madeleine Fagan's book attempts to provide both an explanation for and a way out of this impasse. Her legitimate suspicion is that post-structuralist discourses tend to reproduce a foundationalist sensibility that separates ethics from politics and subsequently attempts to construct an appropriate type of politics corollary to post-structuralist ethics. To the extent they do so, they tend to fall victim to an abstract theorising that reinstates the search of absolute and secure foundations. Instead, she argues for a conception of ethics and politics appropriately permeated by a post-foundational ontology that prioritises a fusion of ethics and politics into what she calls 'practical politics', ethos or 'conduct' (p. 138).

In Chapter 1, Fagan maps out what is wrong with some interpretations of the poststructuralist type of engagement with ethics and politics. Fagan's targets here are mainly David Campbell and Simon Critchley. They are both read as examples of theorists who have succumbed to the foundationalist double bind; they either separate politics and ethics to such an extent that the passage from ethics to politics becomes problematic, or they employ ethics as 'first philosophy' or 'ground' for politics, which is seen as inconsistent with their post-foundational orientation. This part of Fagan's argument, although not always fair or accurate to the claims made by Campbell and Critchley, does identify a fundamental aporia at the heart of poststructuralist ethics. The affirmative stance that critics often find lacking in the Levinasian impossible demand of the Other or the Derridian undecidable, and which

(C) 2015 Macmillan Publishers Ltd. 1470-8914 Contemporary Political Theory Vol. 14, 2, e216-e219 
Campbell and Critchley strive to remedy, is precisely the foundationalist blackmail that post-structuralist ethics seek to indict and transcend in the first place.

Fagan sets out in Chapter 2 to demonstrate how Levinas' approach to politics, especially read through Otherwise than Being, introduces the idea of the Third not as a disruption, a failing or a limitation of the face-to-face ethical relation with the Other, but as a reminder that politics in the form of the plurality of the many always already inhabits ethics. For Fagan, this realisation delivers us from construing the ethical relation as something separate from the plurality of Others within which the sensible self finds itself. Fagan's bold claim here is that we need to read Levinas as a thinker of relationality and plurality almost in alignment with similar thinkers of the political such as Arendt and Lefort, although unfortunately she does not seem to be interested in pursuing these connections.

In Chapter 3, Fagan examines the thinker who plays the role of a transitional figure in her argument from Levinas' implicit relationality to Nancy's explicit relationality: Jacques Derrida. In what is perhaps the best chapter of the book, Fagan does a very good job foregrounding Derrida as the thinker who refuses to deduce politics from ethics and remains faithful to the constitutive aporia of the undecidable. Fagan's insistence that undecidability privileges no particular type of politics - not even, as Campbell would have it, a 'politics of alterity' - but remains a risky business, pushes the theorisation of the ethico-political to its limits. Deconstruction cannot be other than the negotiation of this limit and the signifier of an aporetic relationality that refuses to succumb to either the impossibility of the ethical demand or the conditionality of justice and political calculation; either the outside of a theoretical viewpoint or the inside of pure ethical experience. This almost tragic 'place of nonplace', 'clause of non-closure' (p. 97), described by Lacan's neologism as extimacy, is deconstruction's uncompromising predicament.

Having established the framing of the relationship of ethics and politics as theorising at the limits, Fagan moves to examine the conceptual resources offered by the thought of Jean-Luc Nancy. In a paradoxical shift to a thinker who proposes a Heidegger-inspired return to the primacy of ontology as opposed to the Levinasian notion of the priority of the ethical relation, Fagan argues that post-structuralist ethics need not rely 'on transcendent alterity as the only means by which we might think through the possibility of resistance to totalisation' (p. 100). Her intuition that pure exteriority is perhaps not the best strategy available to disrupt totalisation finds confirmation in Nancy's concept of transimmanence. For Nancy, relationality or existence as 'being-in-common' is the ontological horizon within which the various articulations of the relationship between ethics and politics are structured. Nancy emerges, for Fagan, as the best candidate to foreground the detachment yet at the same time the non-separation of politics from ethics. If Levinas thinly gestures towards the fusion of alterity's absolute exteriority with the Third while Derrida points to the at once impossibility and necessity of the ethico-political, Nancy takes us to an ontology of the 'being-singular-plural' where ethics do not occupy the first 
place. Neither is alterity seen as the sole resistance to totalisation. Rather, the relation without content, the 'hyphen' in the singular-plural, is primary.

Fagan's imaginative inversion of post-structuralist ethics has come full circle. Contrary to prevalent readings, post-structuralist ethics are likely to remain susceptible to the charges of inconsistency, relativism or irrelevance to the extent that they prioritise the absolute exteriority of alterity as an ultimate ground for launching a politics of difference. Indeed, it is doubtful whether the Levinasian ethical relation manages to escape the foundationalist implications of grounding subjectivity on absolute heteronomy. Levinas himself seems to be conscious of the danger of a relapse to the antinomic structure of Kantian ethics, but Fagan is probably right that some of his eager heirs have not always managed to avoid reintroducing what the Levinasian notion of an ethical relation sought to unravel in the first place. ${ }^{1}$

Fagan's concluding plea is for a vision of the ethico-political 'grounded' on practical politics and an open ontology of the political that would be sufficiently receptive to multiple, antagonistic and inherently undecidable configurations of the relationship between ethics and politics. The main concern here behind the voicing of similar sensibilities is French philosophy's obsession with totalisation and depoliticisation. This apprehension is usually expressed as a suspicion towards totalising ethical discourses or political messianisms that attempt to bring closure to the political. That Fagan starts off with the Levinasian priority of absolute exteriority and ends up with a version of post-foundational political ontology is not a coincidence but an indication of the 'wager' within which the latest editions of post-structuralist ethics operate.

The danger of depoliticisation, in other words of the effacement of contingency, alterity, difference and singularity, cannot be thwarted by simply prioritising the latter terms. This would only lead to a new affirmation - this time of difference, alterity and singularity - that would not disrupt the established hierarchies but simply reverse them. Structurally, the discussion takes place on foundationalist terrain as the anti-foundationalists appear negating or inverting what they have first to presuppose in order then to discard. At the same time, foundationalism itself is caught within its own condition of impossibility: whenever it is employed, it generates its own excess/ negation - the category of 'anti-foundationalism' - thereby undermining the possibility of an ultimate, unconditional ground or essence. What seems to produce the impasse here is not the search for self-grounding but the understanding of foundations as presence, as an ultimate ground of the political. What is needed, instead, is an alternative theorising of foundations that would build on the aporia of their own impossibility and necessity without resurrecting the spectres of ultimate foundations. That would, in turn, introduce the possibility of a post-foundational politics faithful both to the experience of order and continuity and to that of temporality and change.

It is for this reason that I wonder whether Fagan's dismissal of theory and of the need for a meta-theoretical 'terrain' from which one can think critically about the 
relationship between ethics and politics is too quick. What she does not explore in this otherwise interesting and provocative book is the terms of a sustainably reflexive post-foundational ontology. To be fair, at the end of the book she seems to embrace such an orientation that would recast ethico-political theorising as a meta-theoretical critique of depoliticisation: 'given the focus on the ethico-political as "how we are", the ways in which this is recognised or covered over, ways in which appeals to the transcendental are made and the perceived need to do this for legitimation would be a fruitful line of enquiry' (p. 152). Yet, more could be said or explored on this point such as why is it that even though the ethico-political is our ontological horizon (we already find ourselves in it), we tend to treat it as an exteriority (ground)? Is there a psychological mechanism, a conceptual limit or an existential condition behind such a predicament? Or, what is the appropriate meta-theoretical articulation of the relationship between ethics and politics, one that would prevent a relapse either to the absolutisation of ethical exteriority or the evasion of ethical responsibility. Is an exhortation for a return to 'practical politics' (p. 138) enough, or does it have to address the issue of the difference between the priority of relationality on the ontological level and the possible manifestation of contingency as totalisation in the ontic one? For depoliticisation can also emerge not only from misrecognising necessity and naturalness where there are only impermanent and contestable social arrangements, but also from the temptation to view contingency and openness as an ontic given, as opposed to an ontological axiom, signifying the $a$ priori failure of any reconciliation between a recalcitrant political reality and our ethical ideals.

\section{Note}

1 Yet it should be noted that in his latest book Critchley (2012) seems to be shifting to a more tragic reading of the relationship between ethics and politics less determined by the absolute priority of the Levinasian ethical demand.

\section{Reference}

Critchley, S. (2012) The Faith of the Faithless: Experiments in Political Theology. London and New York: Verso.

Vassilios Paipais

University of St. Andrews, St. Andrews KY16 9AJ, UK vp31@st-andrews.ac.uk 